years to do in reclaiming the Pontine marshes. Many parks, too, have been ploughed up. Golf courses are not so valuable, but where they can make a substantial contribution they will be asked to do so, while those unsuitable for ploughing will be used for grazing sheep.

In regard to research, the Agricultural Research Council is to be granted an increased sum for use at its unfettered discretion for promoting basic or fundamental research (see also p. 434 of this issue of NATURE). Thus it is hoped to use for the advantage of agricultural research the best brains of the scientific world. The Minister proposes to appoint for England and Wales a body which will be directly responsible to him and which will be concerned to devise methods for ensuring that promising results of research are applied as rapidly as possible to the problems of agriculture and incorporated in the everyday practice of the farmer. A similar body is to be appointed for Scotland. The question of the reform of agricultural education is also to be considered.

\section{Science and Democracy}

The American Association for the Advancement of Science recently forwarded to the British Association a resolution adopted by its Council, inviting the collaboration of British men of science with their American colleagues in framing a charter of democracy on scientific principles. The resolution was passed to express whole-hearted support of the rights of free peoples of the world and the desire of scientific men to share in the responsibility of maintaining them at this time of international stress. It was intended as a significant joining of 'hands across the sea' in a common cause and with the hope that the grasp might lead to effective action.

When this expression of unity of feeling and purpose with Great Britain in the present War was communicated to the Council of the British Association, the resolution was referred to the Committee of the Division for the Social and International Relations of Science. It need scarcely be said that the friendly approach from the United States was highly appreciated, and the co-operation suggested was gladly undertaken. The wording of the American resolution invited co-operation "in attempting to formulate, upon scientific principles, an international charter of democracy". It became clear, however, from inquiries that this phrase represented an attitude and a hope, and was not intended to be a precise term of reference for any committee which might be appointed by either of the two Associations to consider the subject. The Committee of the British Association Division therefore decided first to formulate a statement of the democratic fellowship of science, believing that such a charter would include the basic elements of scientific principles of democracy. This charter has been drafted and communicated to the American Association as well as to the Council of the British Association, as a contribution to the co-operative effort of Englishspeaking scientific communities to promote the advancement of knowledge and action in an international spirit. Whether a charter of the scientifio commonwealth can be made the foundation of a world fellowship has yet to be considered.

\section{University of Liverpool: Air Raid Damage}

IN a recent raid on Liverpool some of the University buildings suffered damage. One of the engineering laboratories received a direct hit and was practically wrecked. Part of the Medical School was also severely damaged, but the effect here was less direct and the structure is not seriously im. paired. Other buildings of the University suffered from blast, many windows, roof-lights, and doors being destroyed. There is, however, no reason to fear that the work of the University will be restricted; the remaining engineering laboratories are adequate to carry on the work of the Faculty with little reduction of efficiency, and repairs are proceeding rapidly on the other laboratories. The amount of the damage is estimated to be about $£ 100,000$, so far as it can be ascertained at present. Fortunately, there was only one casualty and that of a minor kind.

\section{Engineers' Achievements under Aerial Bombardment}

THE twenty-first annual general meeting of the British Electrical Development Association was held in London on March 21 under the presidency of Lord Lytton. The meeting was preceded by a luncheon at which the Minister of Transport was the guest of honour. In reply to Colonel Moore-Brabazon, Lord Lytton pointed out that, in the last twelve months, the electrical industry has undergone the severest test in its existence. In spite of air attacks, electricity supply has suffered no prolonged interruption, but fow of the general public have any idea what this has meant. Too many are apt to take it for granted, like all the other machinery of civilized life to which they are accustomed. In the first place, this 'main. tained supply' was due to improvements in the distributing system which were carried out in the years before the War. It would not have been possible at the time of the War of 1914-18. The national pool of the whole industry, the interconnexion of the mains of different supply authorities and the amalgamation of different competing authorities-measures taken during peace-timomade 'maintained supply' possible. But even so, the results achieved during the past year have been due to the individual bravery of the men who operated the supply.

Lord Lytton expressed the hope that the day is not too far distant when we shall again think more in terms of 'development', because, despite the alarums and excursions of war-time days, the electrical industry has an eye-and a very constructive eyeto the future. In so far as anyone can visualize the problems of reconstruction with which we shall be concerned when the War is ended and the means available in solving them, the Association and various sections of the industry have given considerable thought to the many ways in which electricity can 